\title{
RAPID DETECTION OF MICROBIAL CONTAMINATION IN GHANA- IAN HERBAL MEDICINES BY PCR ANALYSIS
}

\author{
D. DEI-TUTUWA*, P. AMUNA and M. A. RAHMAN \\ School of Science, University of Greenwich, Central Avenue, Chatham Maritime Medway, Kent ME4 4TB, \\ United Kingdom \\ *Present address: Food and Drugs Authority, P. O. Box CT 2783, Cantonments-Accra, Ghana.
}

DOI: http://dx.doi.org/10.4314/gmj.v48i2.9

Corresponding Author: Dr.M.A.Rahman

Email:m.a.rahman@greenwich.ac.uk

Conflict of Interest: None declared

\section{SUMMARY}

Background: There is widespread use of herbal medicines across the world and the need for regulatory measures to ensure their safety, efficacy and quality is therefore imperative. Conventional microbiological methods are used in carrying out quality control analysis of herbal medicines but these are often slow, may be less sensitive or specific and labour-intensive. In this study we investigated the ability to use Polymerase Chain Reaction (PCR) as a fast, accurate and inexpensive novel method to detect the presence of common pathogens in herbal medicines from Ghana.

Methods: We employed different DNA extraction techniques including TE buffer, boiling method for DNA extraction as well as commercially available DNA extraction kits from Qiagen, UK: Gentra Puregene Yeast/Bact. Kit and DNeasy ${ }^{\mathrm{TM}}$ Tissue Kit which is column based to identify Escherichia coli, Staphylococcus aureus and Salmonella sp. in herbal products from Ghana in local African shops on the UK market.

Results: The TE buffer and boiling methods did not yield any bacterial DNA, however both commercial kits yielded significant amounts of DNA. PCR was able to detect pathogens present in the samples directly. Escherichia coli could be detected at $10 \mathrm{cfu} / \mathrm{ml}$ whilst Staphylococcus aureus was detectable at a threshold of up to $10^{3} \mathrm{cfu} / \mathrm{ml}$ when samples were enriched overnight. Salmonella sp. could not be detected in DNA samples extracted from herbal medicines.

Conclusion: We conclude that PCR and similar new molecular techniques such as Real Time PCR have the potential as rapid microbiological analytical techniques especially in busy clinical settings and for quality control of herbal medicines.

Key words: Herbal medicine, Microbial contamination, PCR, Ghana

\section{INTRODUCTION}

Traditional medicine is one of the oldest medicines used for centuries especially in many developing countries. Currently, WHO estimates that about $70-80 \%$ of the world's population, especially in developing countries, still depend on alternative or complimentary medicines including herbal remedies as their primary therapeutic. ${ }^{1}$ The rising use of herbal medicines has seen an increase but there are issues related to quality and safety. The effect of quality in ensuring the safety and efficacy of herbal medicines has been extensively reviewed by several authors. ${ }^{2,3}$ The quality of herbal medicines can be compromised due to the use of poor quality raw materials and the lack of effective controls thereby resulting in low quality of products. Herbal medicines are considered by some to be of a lower risk compared to orthodox medicines, but that notwithstanding, they cannot be said to be completely free from issues pertaining to toxicity and other adverse effects. $^{4}$

Thus protocols and guidelines on safety, quality and toxicity testing have been developed by reputed international organizations ${ }^{5,6}$; the European Medicines Agency $^{7,8}$ and the European Food Safety authority ${ }^{9}$ to help both the manufacturer and regulatory authorities to effectively assess and address these issues. Contaminants of herbal medicines are undesirable and potentially hazardous materials introduced during their handling at various stages of production. These contaminants have been grouped as chemical and biological contaminants, by the WHO10. Chemical contaminants are made up of heavy metals, residues from pesticides and agrochemicals and organic solvents used during processing. ${ }^{10}$

Common biological contaminants may include microorganisms - bacteria, fungi, some parasites and animals such as insects. 
Microbial contamination can occur during the collection of raw materials and processing them into finished products due to poor quality control and hygiene practices during manufacture. ${ }^{11}$ Faecal contamination may occur by the use of manure during cultivation of the plant, and also from the soil and contaminated water during processing, resulting in the introduction of pathogenic microorganisms such as Escherichia coli and Clostridium spp. into the products.

Regulation of herbal products is intended to give the consumer the assurance that the product is safe, of good quality and efficacious. Regulation of herbal medicines differs from country to country, the differences being primarily due to differences in cultural practices and the fact that herbal medicines are rarely studied scientifically.

In Ghana, the Food and Drugs Authority, (FDA) is responsible for the regulation of herbal medicines manufactured or imported into the country ${ }^{12}$ and seeks to ensure that herbal medicines are safe, of good quality and effective to protect the consumer. The Quality Control Laboratory of the FDA is in charge of choosing analytical methods to assess the quality of a product. Currently, the laboratory uses the United States Pharmacopeia (USP) methods for Microbiological Examination of Non-sterile products and tests for specific organisms for the microbiological assessment of herbal medicines.

These standard microbiological methods are used to detect bacteria by employing morphological and biochemical methods to identify microorganisms ${ }^{13}$ and also rely on the use of selective and or enrichment media to evaluate the microbiological quality of products. ${ }^{14}$ Whereas, most bacteria can be cultured using standard microbiological methods, they are usually very slow, thus taking days to arrive at a conclusion. Other disadvantages include difficulty in identifying different species and strains of bacteria, specificity of methods to particular species and the ability to recover bacteria from a sample matrix to be analysed. ${ }^{15}$

To overcome these challenges, several other methods have been developed such as Polymerase Chain Reaction (PCR) to detect microorganisms in a wide range of samples by amplifying specific segments of DNA or genes in an organism. ${ }^{16}$ The focus of this present study was to detect microbial contamination in herbal medicines collected from the Ghanaian market, targeted at children who may be particularly vulnerable because of their lack of fully developed immune system. The specific aim was to detect the presence of contaminants specifically E. coli, $S$. aureus and Salmonella sp. in herbal medicines by PCR using different DNA extrac- tion protocols in order to reduce the time spent when using existing standard traditional microbiological methods.

\section{MATERIALS AND METHODS}

Seven different herbal medicines from different manufacturers originating from Ghana were purchased randomly from African shops in London, UK, processed and analysed in the Microbiology laboratory at the University of Greenwich using the following protocol:

\section{Performing Total Viable Count on Herbal Samples}

In order to establish the presence of microorganisms in the samples, a Total Aerobic Microbial Count was undertaken using USP method for Microbial Examination of Non-sterile Products: Microbial Enumeration Test was used. ${ }^{17}$

\section{DNA Extraction Methods}

DNA extraction using TE Buffer

TE buffer method described by Jimenez et al. ${ }^{18}$ was used some modifications. $1 \mathrm{ml}$ of each sample was put into a sterile Eppendorf tube and then centrifuged at $10,000 \mathrm{rpm}$ for 10 minutes and the supernatant decanted leaving the cell pellets. $200 \mu \mathrm{l}$ of TE buffer $(10 \mathrm{mM}$ TRIS-HCl, EDTA-1mM, pH 8.0) was added to the cell pellets. $6 \mu \mathrm{l}$ of $10 \mathrm{mg} / \mathrm{ml}$ of proteinase $\mathrm{K}$ solution (Promega, USA) and 0.5\% Tween 20 were then added to the cell pellet solution and the mixture incubated at $55^{\circ} \mathrm{C}$ for 20 minutes to lyse cells and degrade cellular proteins. Samples were then transferred to the heating block (Digi-block ${ }^{\mathrm{TM}}$ USA) and incubated at $95^{\circ} \mathrm{C}$ for 10 minutes. The resultant solution was centrifuged at $10,000 \mathrm{rpm}$ for $3 \mathrm{mins}$ and the supernatant decanted. Gel electrophoresis $(0.8 \%$ agarose and $5 \mu \mathrm{g} / \mathrm{ml}$ of ethidium bromide) was run using $10 \mu 1$ of the supernatant to check the quality of the extracted DNA.

\section{DNA Extraction by the Boiling Method}

Boiling method also described by Jimenez et al. ${ }^{18}$ was employed using $1 \mathrm{ml}$ each of sample in a sterile Eppendorf tube and centrifuged at $10,000 \mathrm{rpm}$ for $10 \mathrm{mins}$ to pellet cells. The supernatant was decanted and discarded and $200 \mu 1$ of sterilized distilled water added to the cell pellets. This was incubated in a heating block at $100^{\circ} \mathrm{C}$ for $10 \mathrm{mins}$. The solution was immediately transferred onto an ice bath for $3 \mathrm{mins}$ to cool and the resultant solution centrifuged at $10,000 \mathrm{rpm}$ for $3 \mathrm{mins}$, the supernatant decanted and used for gel electrophoresis.

\section{Use of DNA extraction Kits}

Gentra Puregene Yeast/Bact. Kit and DNeasy ${ }^{\mathrm{TM}}$ Tissue Kit both from Qiagen, UK was used in this experiment. $1 \mathrm{ml}$ of each sample was pipetted into Eppendorf tubes and centrifuged at $5000 \mathrm{rpm}$ for $10 \mathrm{mins}$. Cell pellets were then collected and protocols for each of the kits 
followed to extract DNA. For Gram positive bacteria, the cell pellets were frozen in liquid nitrogen and then thawed under room temperature for three consecutive times, to lyse the cell wall instead of using a Lysis Buffer. Gel electrophoresis was run on $10 \mu 1$ of the resultant DNA.

Spiking and Enrichment of Samples to determine the Limit of Detection

Pure cultures of E. coli and S. aureus obtained from the Microbiology Laboratory with known number of colony forming units $(\mathrm{cfu} / \mathrm{ml})$ was spiked into $10 \mathrm{ml}$ of a sample containing no microorganism to obtain counts from 10 to $10^{4} \mathrm{cfu} / \mathrm{ml}$ separately, for each organism. DNA was extracted from these spiked samples using Gentra Puregene Yeast/Bact. Kit. $1 \mathrm{ml}$ of the spiked samples was inoculated into $9 \mathrm{ml}$ of Tryptone Soy Broth medium (Oxoid, UK) and incubated overnight at $37^{\circ} \mathrm{C}$ to enrich the cells and DNA extracted.

\section{Polymerase Chain Reaction}

\section{Primers}

Specific primers (Sigma-Aldrich, UK) targeted at the following genes: tuf with sequences as 5TGGGAAGCGAAAATCCTG-3(forward),5-

CAGTACAGGTAGACTTCTG-3(Reverse) for E. coli, catalase:5-TTCGAAGCCATTGAAAAAGG3(forward),5-ACATCATCCGTTACGCCTTC-

3(Reverse), for S. aureus and 16S RNA, 5TGTTGTGGTTAATAACCGCA-3(Forward), 5CACAAATCCATCTCTGGA-3(Reverse) for Salmonella were designed to amplify a $258 \mathrm{bp}, 641 \mathrm{bp}$ and

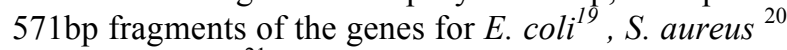
and Salmonella. ${ }^{21}$ were used in this study.

A stock primer solution of $100 \mu \mathrm{M}$ for each primer was prepared as per the manufacturer's instructions and kept in $-20^{\circ} \mathrm{C}$ from which $10 \mu \mathrm{M}$ of working solution was prepared.

\section{Polymerase Chain Reaction experiment}

PCR was performed using the extracted DNA from each of the samples. A total reaction volume of $20 \mu \mathrm{l}$ was used, which contained $10 \mu \mathrm{l}$ Taq mix (Promega, USA), $1 \mu 1$ each of $10 \mu \mathrm{M}$ both forward and reverse primer solutions, $1 \mathrm{mM} \mathrm{MgCl}_{2}, 3 \mu \mathrm{l}$ Rase/ DNase free water and $5 \mu \mathrm{l}$ DNA template extracted from samples. A negative control was performed by replacing $5 \mu 1$ of DNA template with water whiles a positive control contained $5 \mu 1$ of DNA extracted from pure cultures of each organism. PCR assays were performed in GenePro PCR machine (Alpha Laboratories, UK).
The PCR progamme used consisted of initial denaturation, $94^{\circ} \mathrm{C}$ for $5 \mathrm{mins}, 30$ cycles for denaturation, $94^{\circ} \mathrm{C}$ for $1 \mathrm{~min}$, annealing, $45^{\circ} \mathrm{C}, 60^{\circ} \mathrm{C}$ and $55^{\circ} \mathrm{C}$ for $E$. coli, $S$. aureus and Salmonella sp. respectively for $30 \mathrm{~s}$, and extension, $72^{\circ} \mathrm{C}$ for $1 \mathrm{~min}$ and a final extension at $72^{\circ} \mathrm{C}$ for 5mins. After PCR, $10 \mu \mathrm{l}$ of the PCR product was run on $1 \%$ gel. Bands were observed under UV light and photographs taken using Epichemi imager (UVP Bio imaging Systems, UK).

\section{RESULTS}

The presence of microorganisms in the samples was established by performing Total Aerobic Microbial Count the results of which showed that microbial contamination ranges from $0->3.0 \times 10^{6} \mathrm{cfu} / \mathrm{ml}$. Only 1 out of the 7 samples analyzed had no microbial growth. This was therefore used to perform the spiking and enrichment test for determination of Limit of Detection.

For DNA extraction employing the different methods described above there was no DNA yield from the TE Buffer and Boiling methods (1 and 2). Employing DNA Extraction kits in method (3) however yielded good quality DNA, seen from the gel electrophoresis run using the DNA solution shown in (Figure 1.) below.

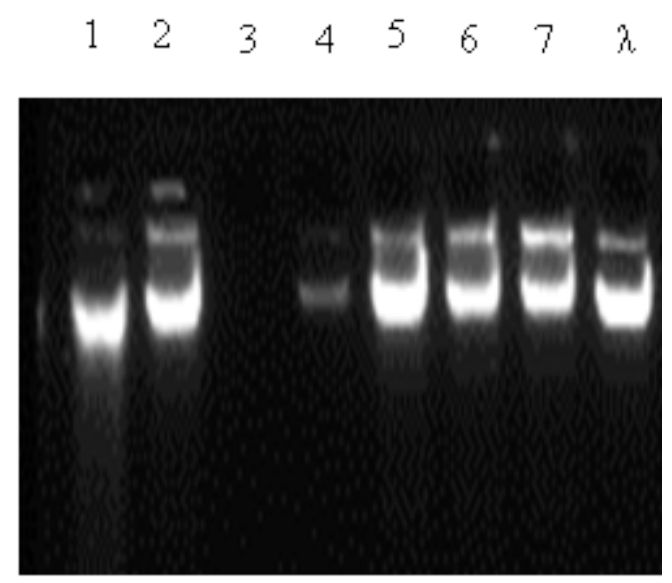

Figure 1 Photograph of agarose gel electrophoresis showing bands for genomic DNA extracted from the different herbal samples. Lanes: $\lambda$ - Lamda Phage DNA used as marker, 1 - sample 1, 2 - sample 2, 3 - sample 3, 4 - sample 4, 5 - sample 5,6-sample 6, 7 - sample 7 .

PCR assay results on samples showed bands for E. coli and $\mathrm{S}$. aureus for 1 sample each. However no was band observed for Salmonella sp. 
Bands were observed at $258 \mathrm{bp}$ for E. coli and $641 \mathrm{bp}$ for $S$. aureus as expected from the product sizes of the primers used and clearly observed in sample 2 in both gels.

To find out the detection limits of theses microorganism drug samples were spiked with $10-10^{4} \mathrm{cfu} / \mathrm{ml}$ of $\mathrm{E}$. coli and S. aureus separately and subsequent extraction of DNA and PCR performed. PCR analysis was carried out on both non-enriched and enriched samples to compare the effect of sample enrichment and any sample which did not have any growth on Tryptone Soy Agar was spiked with different concentrations of E. coli and S. aureus cells (separately). Concentrations of cells ranged from $10-104 \mathrm{cfu} / \mathrm{ml}$ for both organisms. Overnight cultures were also prepared. DNA was extracted for all concentrations for both organisms. PCR assays were conducted using DNA extracted from the spiked samples, both enriched and non-enriched. The results obtained are displayed in (Figure $2 \mathrm{~A}$ and $2 \mathrm{~B}$ ).

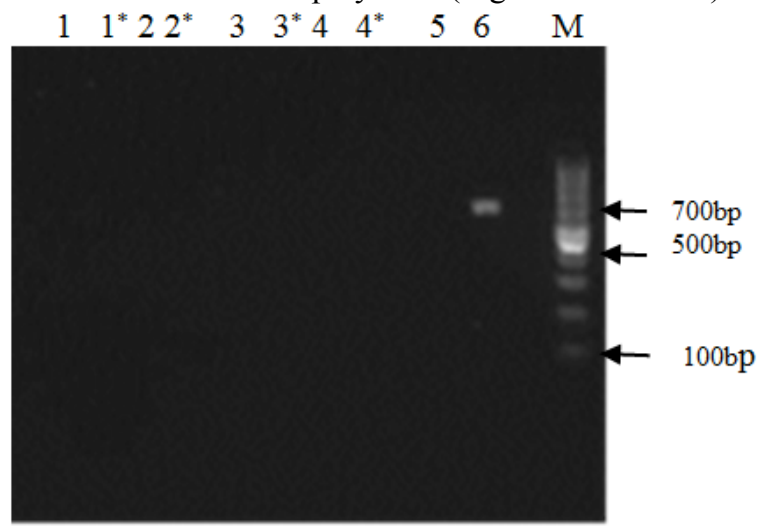

$2 A$
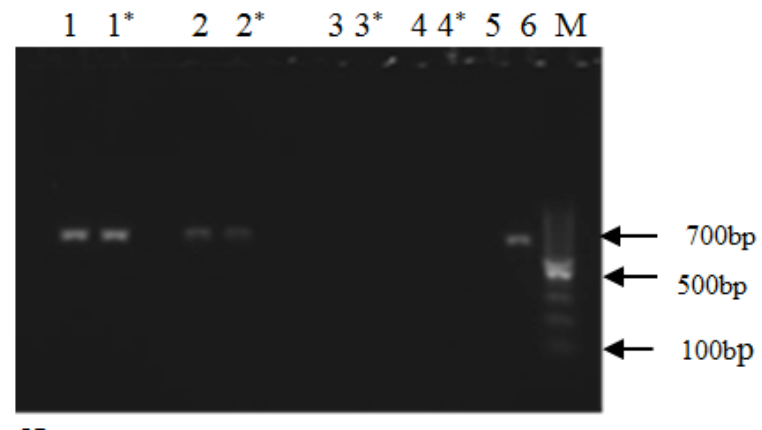

2B

Figure 2 Photograghs of agarose gel electrophoresis of PCR products using S. aureus specific primers. 2A. (spiked only). Lanes: M 100bp DNA Marker, 1, 2 , 3, 4 - sample spiked with $10,10^{2}, 10^{3}$ and $10^{4}$ respectively , 5 - negative control and 6 - positive control. 2B. (spiked and enriched overnight). Lanes: $\mathrm{M}-100 \mathrm{bp}$ DNA Marker, 1, 2, 3, 4 - sample spiked with $10^{4}$, $10^{3}, 10^{2}$, and 10 respectively , 5 - negative control and 6 - positive control. (Lanes with * are duplicates).
Results for S. aureus showed that PCR could only detect samples spiked with $10^{3}$ and $10^{4} \mathrm{cfu} / \mathrm{ml}$ and enriched overnight. There was no detection for all nonenriched spiked samples and samples spiked with $10^{2}$ and $10^{3} \mathrm{cfu} / \mathrm{ml}$ and enriched overnight. Bands were observed between $600 \mathrm{bp}$ and $700 \mathrm{bp}$ which was to be expected (Figures $2 \mathrm{~A}$ and $2 \mathrm{~B}$ ).

However, in case of E. coli PCR detected as low as $10 \mathrm{cfu} / \mathrm{ml}$ from spiked samples for both enriched and non-enriched samples. The only difference between enriched and non-enriched samples was the band intensities, with the enriched samples being more intense (Figure 3).

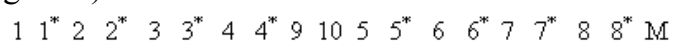

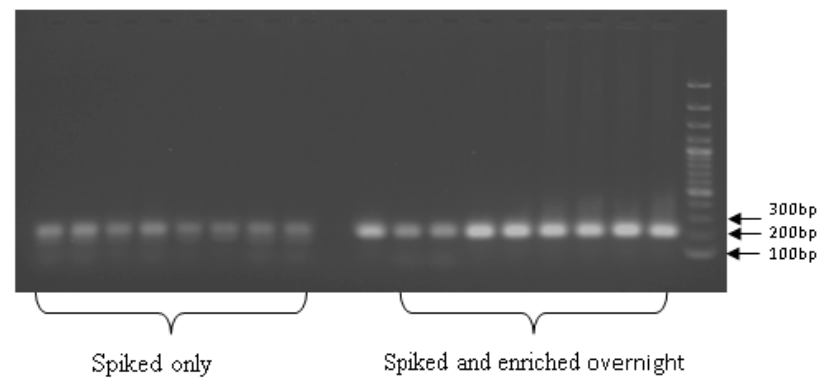

Figure 3 Photogragh of agarose gel electrophoresis of PCR products for E.coli. Lanes: $M-100 b p$ DNA Marker, Spiked-only samples, lanes 1, 2, 3 and 4 represent spiking from $10^{4}-10 \mathrm{cfu} / \mathrm{ml}$ respectively and for spiked and enriched, lanes 5 - 8 represent spiking from $10-10^{4} \mathrm{cfu} / \mathrm{ml}$ respectively. * represents duplicate samples Lane 9 - negative control and Lane 10 - positive control for E. coli DNA extracted from pure cultures.

\section{DISCUSSION}

Total Aerobic Microbial Count results show microbial contamination of herbal samples ranging from 0 $>3.0 \times 10^{6} \mathrm{cfu} / \mathrm{ml}$. Of these, two samples had contamination levels above $10^{5} \mathrm{cfu} / \mathrm{ml}$, hence failing the WHO limit for aerobic bacteria which is $10^{5} \mathrm{cfu} / \mathrm{ml}$ for liquids. ${ }^{10}$ Similar work has been reported in Kaduna where they assessed contamination of herbal medicinal products marketed in Kaduna Metropolis in Nigeria. They observed total aerobic plate count on average of $\leq 5 \times 10^{7} \mathrm{cfu} / \mathrm{g}$ with a coefficient of determination showing that $28 \%$ of total samples studied had aerobic plate counts above the WHO limit. ${ }^{22}$ Such high values are probably the result of manufacturers failing to follow rules of GMP during the manufacturing process.

Adopting different DNA extraction techniques is a very critical step since the yield and the quality of the extracted DNA has a direct bearing on PCR results. ${ }^{23}$ 
Therefore several DNA extraction techniques were adopted. The use of TE buffer and boiling method to extract bacterial genomic DNA from the samples yielded no DNA.

The use of commercially available DNA extraction kits, Gentra Puregene Yeast/Bact. Kit and DNeasy ${ }^{\mathrm{TM}}$ Tissue Kit (Qiagen, UK) were used to extract the DNA from samples reduced the preparation time needed for reagents in conventional DNA extraction methods. It has also been shown that commercially available kits yield good quality amplifiable products compared to standard methods and in-house extraction methods. ${ }^{24}$ Gram positive bacteria pellets were pre-treated by freeze thawing cycles in liquid nitrogen and at room temperature respectively enabled the effective lysis of the cell wall instead of a Lysis buffer thus saving time and money. Gentra Puregene Yeast/Bact. Kit was used for extracting DNA from the freeze thawed pellets and agarose gel electrophoresis showed DNA indicating that the freeze thaw method is effective for lyses of the cell walls of Gram positive bacteria.

Gel electrophoresis photographs of PCR showed that both E. coli and S. aureus, DNA were amplified in sample 2 where expected product size of $258 \mathrm{bp}$ and $641 \mathrm{bp}$ were observed for E. coli ${ }^{19}$ and $S$. aureus, ${ }^{20}$ respectively. Salmonella sp. was not detected following DNA extraction from samples and was thus probably absent or of low quantity to be detected.

For limit of detection experiment in case of S. aureus, bands were only observed for overnight enriched samples with cell concentrations of $10^{3}$ and $10^{4} \mathrm{cfu} / \mathrm{ml}$ of sample (Figure 2B) but not for non-enriched samples spiked with 10 to $10^{4} \mathrm{cfu} / \mathrm{ml}$ (Figure 2A) and enriched samples with cell concentrations of 10 and $10^{2} \mathrm{cfu} / \mathrm{ml}$ (Figure 2B). In another study it was observed that PCR was able to detect $\mathrm{S}$. aureus at $10^{2}$ to $10^{7} \mathrm{cfu} / \mathrm{ml}$ using the same primers in milk products. Inability to detect $\mathrm{S}$. aureus in non-enriched and lower sample concentrations in this study may be due to the medium, in this case herbal product matrix rather than milk. ${ }^{20}$

Gel electrophoresis results for PCR products for E. coli (Fig 3) for both enriched and non-enriched samples showed bands for all cell concentrations thus indicating that for E. coli, PCR is able to detect as low as 10 $\mathrm{cfu} / \mathrm{ml}$ in herbal medicinal samples. This has been demonstrated elsewhere by others where it was shown that PCR is able to detect E. coli cells between $10-10^{2}$ $\mathrm{cfu} / \mathrm{g}$ in soil samples. ${ }^{25}$

\section{CONCLUSIONS}

We have demonstrated that PCR is able to detect the presence of E. coli and S. aureus in liquid herbal medicinal products. We believe that PCR analysis is a rapid and reliable method with potential time-saving advantages for clinical practice and quality control of herbal medicinal products but this potential merits further exploration.

Despite its usefulness, conventional PCR is however a qualitative method, therefore we also suggest further experiments to explore the use of real time PCR to enable both qualitative and quantitative determination of microbial load in herbal medicines for public health monitoring.

\section{ACKNOWLEDGEMENT}

The authors would like to thank the Food and Drugs Board, Ghana for providing the scholarship which enabled Delali Dei-Tutuwa to carry out this study.

\section{REFERENCES}

1. World Health Organization (WHO) Traditional Medicine 2008

2. De Smet, P.A.G.M. Health risks of herbal remedies: an update. Clin Pharmacol Ther, 2004, 76(1): $1-17$.

3. Bauer R., Quality criteria and standardisation of Phytopharmaceuticals: can acceptable drugs be achieved? Drug Inform. J., 1998,32(1):101-110.

4. De Smet, P.A.G.M. Toxicological outlook on quality assurance of herbal remedies. In: Adverse Effects of Herbal Drugs, vol.1. Berlin: Springer Verlag 1992.

5. World Health Organization(WHO) Quality Control Methods for Medicinal Plant Materials, 1998

6. World Health Organization (WHO). WHO Guidelines on Good Manufacturing Practices (GMP) for Herbal Medicines 2007

7. European Medicines Agency. EMEA Guideline on the Assessment of Genotoxic Constituents in Herbal Substances/Preparations (Draft). 2009.

8. European Medicines Agency,. EMEA Guideline on Selection of Test Materials for Genotoxicity Testing for Traditional Herbal Medicinal Products/ Herbal Medicinal Products (Draft). 2007.

9. EFSA: European Food Safety Authority. Guidance on Safety Assessment of Botanicals and Botanical Preparations Intended for Use as Ingredients in Food Supplements. EFSA J. 2009, 7: 1249.

10. World Health Organization (WHO). WHO Guidelines for Assessing Quality of Herbal Medicines with reference to Contaminants and Residues 2007

11. Sagoo, S. K., Little, C. L., Greenwood, M., Mithani, V., Grant, K. A., McLauchlin, J., de Pinna, E., 
Threlfall, E. J. Assessment of the microbiological safety of dried spices and herbs from production and retail premises in the United Kingdom. Food Microbiol. 2009, 26(1): 39-43.

12. Food and Drugs Board (FDB), Ghana. Law setting up FDB, 2012.

13. Martinez-Bermudez, A., Rodriguez de Lecea, J., Soto-Esteras,T., Vazquez-Estevez, C. ChenaCanete, C. Types of microbial contaminants in pharmaceutical raw materials. J. Lat.- Am. Microbiol., 1991, 33(2-3):153-157.

14. Casey, W., Muth, H., Kirby, J. Allen, P., Use of nonselective preenrichment media for the recovery of enteric bacteria from pharmaceutical products. Pharm Technol, 1998, 22:114-117.

15. Jimenez, L., Smalls, S., Ingar R. Use of PCR analysis for detecting low levels of bacteria and mold contamination in pharmaceutical samples. $J \mathrm{Mi}$ crobiol Methods., 2000, 41 259-265.

16. Giovannoni, S. The polymerase chain reaction. In:, Stackebrandt, E.. Goodfellow, M. (eds), Nucleic Acid Techniques in Bacterial Systematics West Sussex, England. John Wiley and Sons, 1991.

17. United States Pharmacopeia, 2011. USP 34/NF 29, vol 1. The Official Compendia of Standards. Rockville, Maryland, The United States Pharmacopeial Convention, 2011.

18. Jimenez, L., Ignar R., Smalls S., Grech P., Hamilton J., Bosko Y, English D. Molecular detection of bacterial indicators in cosmetic/pharmaceutical samples. J. of Ind Microbiol. Biotechnol, 1999,21(2):93-95.
19. Andrée F. M., François J. P., B. Maurice B., Luc B, Sonia P., Michel G. B. Analytical comparison of nine PCR primer sets designed to detect the presence of Escherichia coli/Shigella in water samples. Water Res., 2009, 43(12): 3019-3028.

20. Riyaz-Ul-Hassan, S., Verma, V. , Qazi, G. N. Evaluation of three different molecular markers for the detection of Staphylococcus aureus by polymerase chain reaction Food Microbiol, 2008, 25(3): 452-459.

21. Lin, C.K, Tsen H.Y. Use of two 16S DNA targeted oligonucleotides as PCR primers for the detection of Salmonella in foods. J Appl Bacteriol, 1996, 80(6):659-666.

22. Abba, D., Inabo, H. I., Yakubu, S. E, Olonitola O. S. Contamination of Herbal Medicinal Products Marketed in Kaduna Metropolis with Selected Pathogenic Bacteria. Afr J Tradit Complement Alternative Med, 2009, 6(1):70-77.

23. Liu, Y.T. A technological update of molecular diagnostics for infectious diseases. Infect Disord Drug Targets, 2008,8(3):183-188

24. Psifidi A., Dovas C.I, Banos G. A Comparison of six methods for genomic DNA extraction suitable for PCR based genotyping amplifications using ovine milk samples. Mol Cell Probes, 2010, 24(2):93-98.

25. Berthelet M., Whyte L.G. ,Greer C.W. Rapid direct extraction of DNA from soils for PCR analysis using polyvinylpolypyrrolidone spun-columns. FEMS Microbiol. Lett, 1996, 138(1):17-22. 